\title{
Determination of Serum Endotoxin Level as an Early Cardiovascular Injury Marker in Obese Children and Adolescents
}

\author{
EMAN M.E. SELF, M.Sc.*; MOHAMMED A. HAMMAM, M.D.*; AMANY M. ABO-ELENEIN, M.D.** and \\ RASHA M.G. EL-SHAFIEY, M.D.* \\ The Departments of Pediatrics* and Clinical Pathology**, Faculty of Medicine, Tanta University, Tanta, Egypt
}

\begin{abstract}
Background: Obesity is defined as a BMI at or above the 95 th percentile for children and teens of the same age and sex. Childhood obesity is associated with chronic low-grade inflammation and cardiovascular disease.
\end{abstract}

Aim of Work: Was to estimate serum endotoxin level in obese children and adolescents and to evaluate its relation with cardiovascular $(\mathrm{CV})$ injury risk in these children.

Subjects and Methods: The current study included 30 patients recruited from the Nutrition Clinic of Pediatric Department at Tanta University Hospital and 15 healthy children and adolescents of matched age and sex enrolled as controls. All studied children were subjected to complete history taking, thorough clinical examination including blood pressure, Anthropometric measures (Weight, height, Body mass index, Triceps skin fold thickness, Waist circumference, Waist/hip ratio, Waist/Height ratio), and laboratory investigations including: $\mathrm{CBC}$, BUN, creatinine, SGOT, SGPT, Fasting glucose, Lipid profile, Serum Endotoxin, abdominal ultrasound.

Results: There were significant differences between patients and control group as regard Blood pressure levels and all anthropometric measures except height. Significantly higher levels of total cholesterol, LDH and significantly lower HDL were found in patients compared to control group. Serum Endotoxin was significantly higher in patients than controls. Significant positive correlation between Serum Endotoxin level and both Systolic, diastolic blood pressure, BMI, Waist circumference, Hip circumference, Waist /Height ratio, serum cholesterol, Serum Triglycerides) were found. Significant negative correlation between Serum Endotoxin and serum HDL was found.

Conclusion: Serum Endotoxin is higher in obese children and adolescents than none obese. Serum Endotoxin is reliable early marker for obesity related cardiovascular injury in obese children and adolescents.

Key Words: Endotoxin - Cardiovascular (CV) injury - Obesity.

Correspondence to: Dr. Eman Mohammed El-Naggar Self, The Department of Pediatric, Faculty of Medicine,

Tanta University, Tanta, Egypt

\section{Introduction}

OVERWEIGHT and obesity are defined as "abnormal or excessive fat accumulation that presents a risk to health" [1]

The measurement of overweight and obesity in children and adolescents needs simple index for evaluation because their bodies undergo a number of physiological changes as they grow Depending on the age, different methods to measure a body's healthy weight are available [2]

Body mass index (BMI) is a measure used to determine childhood overweight and obesity. Overweight is defined as a BMI at or above the $85^{\text {th }}$ percentile and below the $95^{\text {th }}$ percentile for children and teens of the same age and sex. Obesity is defined as a BMI at or above the 95 th percentile for children and teens of the same age and sex [2].

Studies revealed that rapidly changing dietary practices and a sedentary lifestyle lead to increasing prevalence of childhood obesity in developing countries [3].

Important determinants of childhood obesity include high socioeconomic status, residence in metropolitan cities, female gender, unawareness and false beliefs about nutrition, marketing by transnational food companies, increasing academic stress, and poor facilities for physical activity [4]

Global research was done on 2010 showing that 43 million children (35 million in developing countries) were estimated to be overweight and obese. The worldwide prevalence of childhood overweight and obesity increased from $4.2 \%$ in 1990 to $6.7 \%$ in 2010 . This trend is expected to reach $9.1 \%$, or 60 million in 2020 [5] 
In Egypt, a research held by Egypt demographic health survey in 2014 revealed that in boys aged from 5 to 9 years, about $15 \%$ were obese and $39.6 \%$ were overweight, while in girls of the same age, $11 \%$ were obese and $36.4 \%$ were overweight. In boys aged from 10 to 14 years, about $9.9 \%$ were obese and $34.4 \%$ were overweight, while in girls of the same age $8.5 \%$ were obese and $35.4 \%$ were overweight. In boys aged from 15 to 19 years $4.9 \%$ were obese and $29.4 \%$ were overweight, while in girls of the same age $8.7 \%$ were obese and $35.6 \%$ were overweight. About $70 \%$ of obese adolescents grow up to become obese adults [6].

Childhood obesity has been associated with type 2 diabetes mellitus, early-onset metabolic syndrome, subclinical inflammation, dyslipidemia, coronary artery diseases, renal damage and adulthood obesity [7]

Obesity is also strongly associated with several important comorbidities that often contribute to the development of cardiovascular disease (CVD). Most important among these are elevated blood pressure, insulin resistance, and dyslipidemia, 3 key elements of the metabolic syndrome [8].

Childhood obesity is associated with chronic low-grade inflammation considered as a precursor to metabolic disease. However, the molecular mechanisms underlying this association remain largely unclear. Studies in adults have implicated gut derived gram-negative bacterial fragments known as lipopolysaccharide (LPS) or endotoxin, activating the inflammatory response [9]

In physiological conditions, the intestinal epithelium acts as a continuous barrier to avoid LPS translocation; however, some endogenous or exogenous events may alter this protective function [10].

Weight gain has been associated with a higher gut permeability and subsequent systemic exposure to mildly increased LPS circulating levels. Studies demonstrated that a high-fat diet promotes LPS absorption across the intestinal barrier, increasing its plasma levels by two to three times, a threshold defined as Metabolic Endotoxemia (ME) [10].

\section{Subjects and Methods}

This study (Case Control study) was done after approval from ethical committee of research center of Tanta University and written consent from the parents of all children included in this study. The study was conducted on 30 obese children and adolescents, recruited from the Nutrition Clinic, Pediatric Department, Tanta University, in the period from June 2017 to May 2018 including 13 males and 17 females with their age ranged from 8 to 18 years and mean age value of $11.193 \pm 2.441$. This study included also 15 healthy children as a control group including 7 males and 8 females with their age ranged from 8 to 18 years and mean age value of $12.233 \pm 2.796$.

Inclusion criteria: Included Children and adolescent with age ranging from 8 to 18 years and with body mass index (BMI) equal to or greater than the $95^{\text {th }}$ percentile for gender and age.

Exclusion criteria were: Syndromatic obesity (Prader Willi, Laurence-Moon Biedle syndrome, etc), Endocrinal obesity causes such as Cushing's syndrome or hypothyroidism, Children with systemic diseases including liver diseases, malignancy, drug use (corticosteroids, antithyroid drugs, antipsychotic), Children with cardiovascular disease.

All the children in both groups were subjected to the following:

1- Full history taking with special emphasis on: Past history for systemic diseases, Family history of obesity, hypertension and diabetes, Drug administration (corticosteroids, antithyroid drugs, anti-psychotic, use of other drugs), Dietary History.

2- Clinical examination: Including Blood pressure (BP), Thorough medical examination (head \& neck, chest, heart, abdomen, upper and lower limbs).

3- Anthropometric measures and Z-score calculation for (Weight, Height, Body mass index (BMI), Triceps skin fold thickness, Waist circumference, Hip circumference, Waist/Hip ratio and Waist-to-height ratio).

4- Investigations including: Complete blood count, Blood urea nitrogen and Serum creatinine, Serum Glutamic Oxaloacetic Transaminase (SGOT) and Serum Glutamic Pyruvic Transaminase (SGPT), Fasting blood glucose, Lipid profile [Total cholesterol, Triglycerides, Lowdensity lipoprotein (LDL), High-density lipoprotein (HDL)], Serum Endotoxin level by ELISA.

Statistical analysis of the present study was conducted, using the mean, standard deviation and chi-square test by SPSS Version 19. $p$-value $\leq 0.05$ Significant, $p$-value $>0.05$ not Significant, $p$-value $<0.01$ Highly Significant. 
5- Abdominal ultrasound for detection of fatty liver.

\section{Results}

Table (1) shows no significant difference between obese patients and control group as regard age, sex, Height and Height z-score. But Anthropometric measures including (weight, weight $\mathrm{z}$ score, BMI and BMI z- score, Waist/hip ratio, and Triceps skin fold thickness) and Fasting Blood glucose were significantly higher in patient group compared to control group.

Table (2) shows that: Predictors for central obesity (waist circumference, hip circumference and waist height ratio), both systolic and diastolic blood pressure levels, Serum cholesterol, LDL levels and Serum Endotoxin Level were significantly higher in patient group compared to control group, but HDL levels were significantly lower in patients than controls. Serum Triglycerides showed no significant difference between both groups.

Table (3) showed that there were Significant positive correlation between Serum Endotoxin level and (Systolic blood pressure, Diastolic blood pressure, BMI, Waist circumference, Hip circumference, Waist/Height ratio, Total serum cholesterol, Serum Triglycerides). But Significant negative correlation between Serum Endotoxin and serum HDL.

Fig. (1) show that serum endotoxin levels were significantly higher in patients consuming High fat diet than those without high fat consumption.

Table (1): Charactaristics of studied groups.

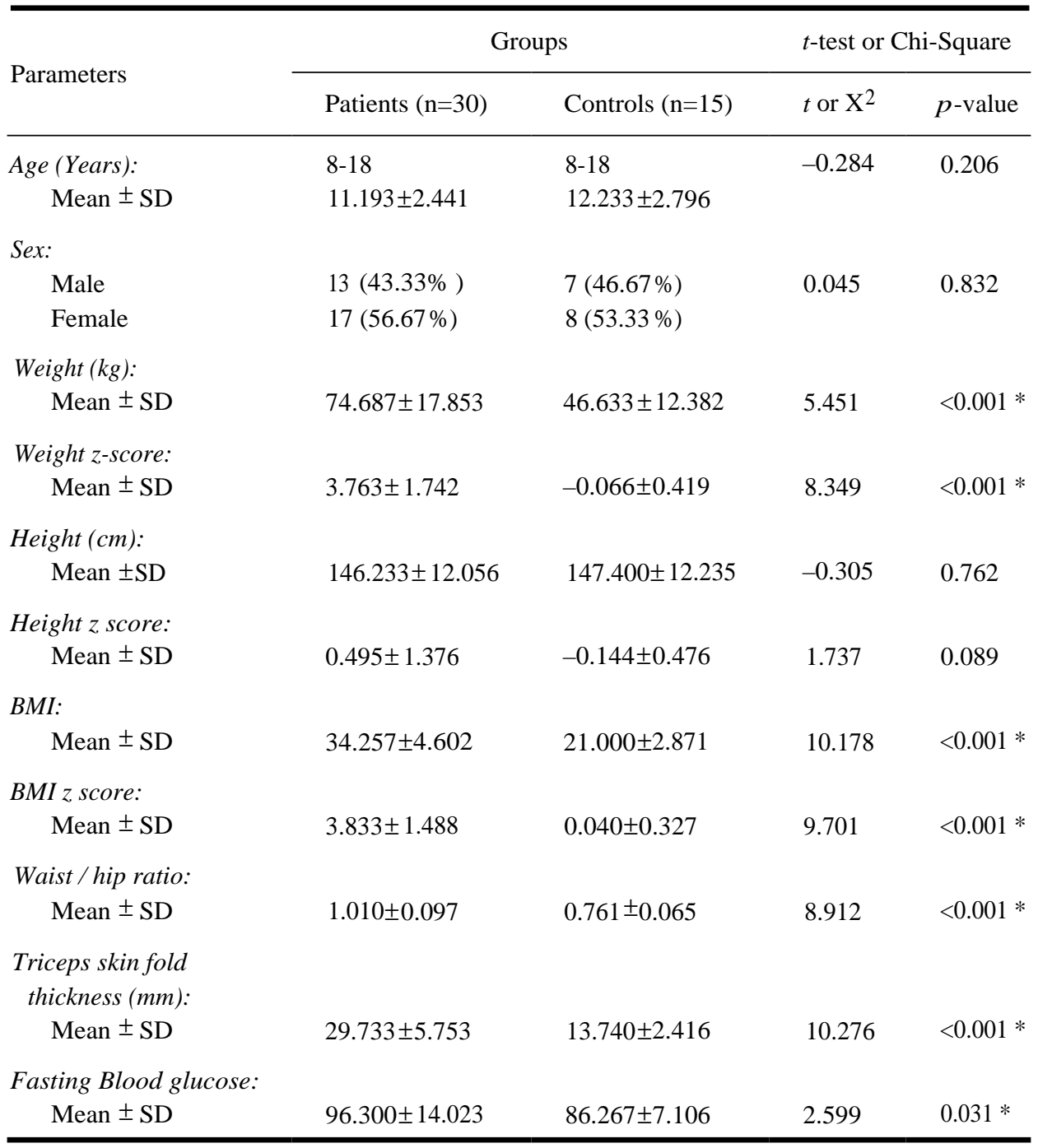


Table (2): Markers for Cardiovascular (CV) risk in studied groups.

\begin{tabular}{|c|c|c|c|c|}
\hline \multirow{2}{*}{ Parameters } & \multicolumn{2}{|c|}{ Groups } & \multicolumn{2}{|c|}{$t$-test or Chi-Square } \\
\hline & Patients $(n=30)$ & Controls $(\mathrm{n}=15)$ & $t$ or $\mathrm{X}^{2}$ & $p$-value \\
\hline $\begin{array}{l}\text { Waist circumference/cm: } \\
\quad \text { Mean } \pm \mathrm{SD}\end{array}$ & $91.817 \pm 15.904$ & $64.667 \pm 6.850$ & 6.298 & $<0.001 *$ \\
\hline $\begin{array}{l}\text { Hip circumference/cm: } \\
\quad \text { Mean } \pm \mathrm{SD}\end{array}$ & $92.687 \pm 21.695$ & $49.000 \pm 4.906$ & 7.660 & $<0.001 *$ \\
\hline $\begin{array}{l}\text { Waist/height ratio: } \\
\text { Mean } \pm \mathrm{SD}\end{array}$ & $0.630 \pm 0.108$ & $0.439 \pm 0.026$ & 6.704 & $<0.001 *$ \\
\hline $\begin{array}{l}\text { Systolic Blood Pressure level }(\mathrm{mmHg}) \text { : } \\
\quad \text { Mean } \pm \text { SD }\end{array}$ & $116.333 \pm 10.080$ & $104.333 \pm 7.037$ & 4.124 & $<0.001 *$ \\
\hline $\begin{array}{l}\text { Diastolic Blood Pressure level }(\mathrm{mmHg}) \text { : } \\
\quad \text { Mean } \pm \mathrm{SD}\end{array}$ & $76.833 \pm 9.513$ & $69.000 \pm 3.873$ & 3.051 & $0.004 *$ \\
\hline $\begin{array}{l}\text { Serum Total cholesterol }(\mathrm{mg} / \mathrm{dl}) \text { : } \\
\quad \text { Mean } \pm \mathrm{SD}\end{array}$ & $185.800 \pm 45.749$ & $109.933 \pm 28.487$ & 5.861 & $<0.001 *$ \\
\hline $\begin{array}{l}\text { Serum Triglycerides }(m g / d l) \text { : } \\
\quad \text { Mean } \pm \text { SD }\end{array}$ & $120.263 \pm 53.410$ & $98.467 \pm 19.086$ & 1.525 & 0.135 \\
\hline $\begin{array}{l}\text { Serum } L D L(m g / d l): \\
\quad \text { Mean } \pm \text { SD }\end{array}$ & $117.627 \pm 28.508$ & $82.667 \pm 11.095$ & 4.558 & $<0.001 *$ \\
\hline $\begin{array}{l}\text { Serum HDL }(m g / d l): \\
\quad \text { Mean } \pm \mathrm{SD}\end{array}$ & $44.040 \pm 5.841$ & $51.333 \pm 6.810$ & -3.736 & $<0.001 *$ \\
\hline $\begin{array}{l}\text { Serum Endotoxin Level }(E u / L) \text { : } \\
\quad \text { Range } \\
\text { Mean } \pm \mathrm{SD}\end{array}$ & $\begin{array}{l}22.513-156.357 \\
46.767 \pm 36.876\end{array}$ & $\begin{array}{l}18.34-40.46 \\
25.215 \pm 6.517\end{array}$ & 2.234 & $0.031 *$ \\
\hline
\end{tabular}

Table (3): Correlations of Serum Endotoxin level with other parameters in the patients group.

\begin{tabular}{lcc}
\hline \multicolumn{3}{c}{ Correlations } \\
\hline & \multicolumn{2}{c}{ Serum endotoxin level (Eu/L) } \\
\cline { 2 - 3 } & \multicolumn{1}{c}{$r$} & $p$-value \\
\hline Systolic BP & 0.433 & $0.017^{*}$ \\
Diastolic BP & 0.414 & $0.023^{*}$ \\
BMI & 0.711 & $<0.001^{*}$ \\
Waist circumference/cm & 0.435 & $0.016^{*}$ \\
Hip circumference/cm & 0.510 & $0.004^{*}$ \\
Waist/height ratio & 0.495 & $0.005^{*}$ \\
Total cholesterol (mg/dl) & 0.458 & $0.011^{*}$ \\
Triglycerides (mg/dl) & 0.690 & $<0.001^{*}$ \\
HDL (mg/dl) & -0.367 & $0.046^{*}$ \\
\hline
\end{tabular}

$r$ : Correlation coefficient.

\section{Discussion}

Obesity among children, adolescents and adults has emerged as one of the most serious public health concerns in the 21 st century. The worldwide prevalence of childhood obesity has increased remarkably over the past 3 decades. The growing prevalence of childhood obesity has also lead to appearance of obesity-related comorbid disease entities at an early age [11].

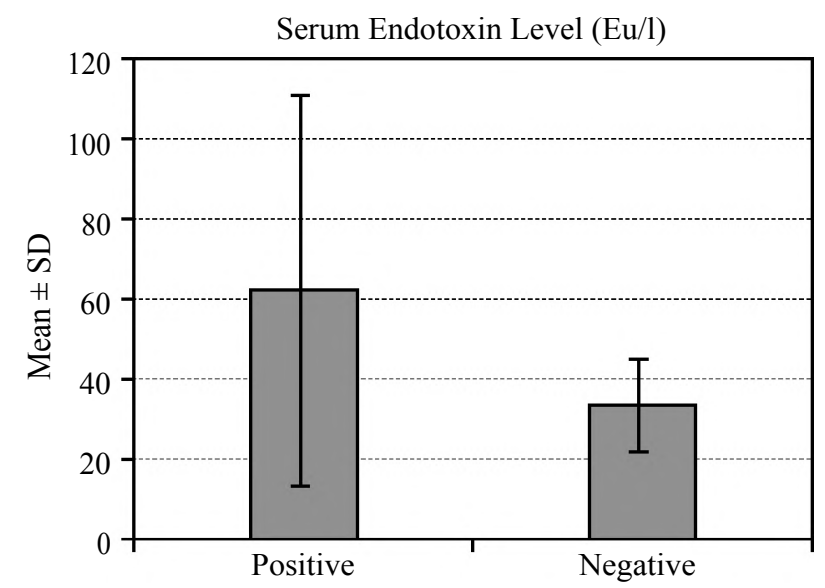

Fig. (1): Comparison of serum endotoxin levels regarding high fat diet in studied patients.

Childhood obesity can adversely affect nearly every organ system and often causes serious consequences, including hypertension, dyslipidemia, insulin resistance, dysglycemia, fatty liver disease and psychosocial complications. It is also a major contributor to increasing healthcare expenditures [11] .

This study was conducted on 30 obese children and adolescents with age ranged between 8-18 years. In our study, there was insignificant differ- 
ence between patients and controls regarding their age, this was in agreement with Goknar et al., [11] El-Karaksy et al., [12] and Sadeghabadi et al., [13]

Waist circumference, being an index for central and visceral obesity, is more related to insulin resistance and its health consequences which has been confirmed by previous studies $[\mathbf{1 4}, \mathbf{1 5}]$. In our study, all patients had higher waist circumference with a statistically significant difference when compared with children in the control group, 22 children $(73.33 \%)$ exceeding the 90th percentile according to the Canadian pediatric endocrine group (CPEG). This agreed with Sadeghabadi et al., [13] ; Boodai et al., [14]; Santomauro et al., [16]; Harte et al., [17] ; Schwander et al., [18] ; Aeberli et al., [19] and Mushtaq et al., [20] .

Hip circumference (HC) of obese individuals in our study was statistically significantly higher than that of children in the control group. This agreed with with Abd-Elghaffar et al., [21], Saki and Karamizadeh [22] and Hassan et al., [23] who found that $\mathrm{HC}$ of obese children showed statistically significant different when compared with a children in the control group.

The Waist Height ratio (W/Ht R) is an easy, accurate, and inexpensive method to assess the over fat condition, cardio metabolic impairments, and chronic disease risk. A ratio $<0.5$ appears to be the optimal healthy cut point in both sexes and among different ethnicities and age groups including children, with the simple notion that one's waist should be less than half their height [24].

In our study WHt R was significantly higher in patients compared to controls, this agreed with Santomauro et al., [16]; Aeberli et al., [19]; Nawarycz et al., [25] and Donma et al., [26] who found that the average WHtR value was significantly different between patients and controls, and was significantly different as per gender. We found that 26 out of $30(86.6 \%)$ had a WHtR $\geq 0.5$, and this percentage was higher than the percentage reported by Mushtaq et al., [20] who found that $16.5 \%$ children had a $\mathrm{WHtR} \geq 0.5$.

Our study showed statistically significant difference in triceps skinfold thickness between obese and non-obese children being higher in obese children. This agreed with Jehn et al., [27], Rinaldi et al., [28] and Aeberli et al., [19].

As regard Blood pressure levels in our study we found that blood pressure is significantly higher in patients when compared with controls. We found that $43.33 \%(n=13)$ were hypertensive (blood pressure above $95^{\text {th }}$ percentile for age and sex) and this percentage was higher than percentage reported by Abd- Elghaffar et al., [21] who found $(8.9 \%)$ of patients were hypertensive, showing high systolic and diastolic blood pressure for age and sex, Kollias et al., [29] reported that the blood pressure value in $(26.2 \%)$ children in the obese group was higher than the $95^{\text {th }}$ percentile value, Wanzhu et al., [30] showed that (14\%) of overweight and obese children had higher blood pressure than normal children and also reported that BP increases as BMI increases and that hypertension is more prevalent in higher BMI categories. The high blood pressure levels in obese children could be explained by the fact that blood pressure is the product of cardiac output and systemic vascular resistance, and cardiac output is increased in obese patients because of increased blood flow to the adipose tissue. Various factors like low-grade inflammation mediated through adipokines, hyperinsulinemia, and insulin resistance cause over-activity of the sympathetic nervous system in obese patients. With increasing severity of obesity, hypertension becomes more prevalent [31].

As regard the presence of metabolic syndrome (MetS) in our study, 53,33\% (16/30) of obese children had metabolic syndrome according to the International Diabetes Federation (IDF) definition, this is higher than that reported by Boodai et al., [14] who found that 17 of the 80 participants (21.3\%) had MetS by the IDF definition, In the study by Giannini et al., [32] MetS was diagnosed in $24.6 \%$ of obese adolescents and $1.9 \%$ of overweight adolescents according to the IDF criteria, this also agreed with El-Karaksy et al., [15] who found that 28 of 76 the participants $(36,8 \%)$ had MetS by the IDF definition.

The prescence of metabolic syndrome in obese children may be due to prescence of risk factors as high waist circumference, high blood pressure levels, high fasting blood glucose level, high Triglycerides and low HDL levels [33]

As regard Lipid Profiles, in the present study: Total serum cholesterol was significantly higher in patients compared to controls, this agreed with El-Karaksy et al., [12]; Boodai et al., [14]; Zoair et al., [34], but this disagreed with Schwander et al., [18] and Sadeghabadi et al., [13] who found that there was no significant difference as regard total cholesterol.

Also serum LDL levels were significantly higher in patients compared to controls, this agreed with El-Karaksy et al., [12], Sadeghabadi et al., [13]; 
Boodai et al., [14]; Schwander et al., [18] and Zoair et al., [34].

Serum HDL levels were significantly lower in patients compared to controls, in agreement with El-Karaksy et al., [12] ; Boodai et al., [14] ; Schwander et al., [18] and Zoair et al., [34], but this disagreed with Sadeghabadi et al., [13] who found that there was no significant difference as regard HDL.

Also we found no significant difference between patients and controls as regard serum triglycerides level, this agreed with El-Karaksy et al., [12], Zoair et al., [34], but disagreed with Sadeghabadi et al., [13] ; Boodai et al., [14] and Schwander et al., [18] who found that there was statistically difference in triglycerides level.

The cause of dyslipidemia in obese children could be explained by the fact that the development of insulin resistance in peripheral tissues leads to an enhanced hepatic flux of fatty acids from dietary sources, intravascular lipolysis and the adipose tissue resistant to the antilipolytic effects of insulin, affect lipid metabolism and lead to dyslipidemia [35].

As regard serum endotoxin level in our study, patient group had significantly higher serum endotoxin level than control group. Our study agreed with Harte et al., [17]; Liang et al., [36] and Varma et al., [9]. On the other hand, Schwander et al., [18], found that there was no significant difference between obese children and non-obese as regard serum endotoxin level.

Weight gain has been associated with a higher gut permeability and subsequent systemic exposure to mildly increased endotoxin circulating levels [37].

We also found that there was no significant difference between males and females in the patient group as regard serum endotoxin level. This disagreed with Varma et al., [9] who found that serum endotoxin levels were significantly higher in obese males than obese females.

We compared serum endotoxin levels in different Dietary patterns in the studied patients and found that there was significant difference in serum endotoxin levels in patients with High fat diet, this agreed with Harte et al., [17]; Schwander et al., [18] ; Deopurkar et al., [38] and Mani et al., [39], who tested endotoxin level before and after giving high fat meal and found that serum endotoxin concentrations were increased after a meal rich in saturated fatty acids.
Studies demonstrated that a high-fat diet promotes endotoxin absorption across the intestinal barrier, increasing its plasma levels by two to three times, a threshold defined as Metabolic Endotoxaemia [10]

In Our Study, we found significant positive correlation between Serum Endotoxin level and both systolic and diastolic blood pressure which agreed with Varma et al., [9]

The present study also revealed significant positive correlation between Serum Endotoxin level and (BMI and Waist circumference) which agreed with Schwander et al., [18].

Significant positive correlation between Serum Endotoxin level and Hip circumference was found in our study. To our knowledge no other studies analysed the correlation between Serum Endotoxin level and Hip circumference.

We also found significant positive correlation between Serum Endotoxin level and (Total serum cholesterol, serum Triglycerides) this disagreed with Schwander et al., [18] who found that there was significant negative correlation between Serum Endotoxin level, serum cholesterol and serum Triglycerides.

Our study revealed significant negative correlation between Serum Endotoxin level and HDL. This finding agreed with Schwander et al., [18].

\section{Conclusion:}

We concluded that Serum Endotoxin is higher in obese children and adolescents than none obese. We also concluded that Serum Endotoxin is reliable early marker for obesity related cardiovascular injury in obese children and adolescents.

\section{Acknowledgements:}

This research was carried out without funding.

Conflicts of interest:

No conflicts of interest declared.

\section{Authors contributions:}

All authors had equal role in design, work, statistical analysis and manuscript writing. All authors have approved the final article work.

\section{References}

1- TYROVOLAS S., KOYANAGI A., OLAYA B., AYUSOMATEOS J.L., MIRET M., CHATTERJI S., et al.: Factors associated with skeletal muscle mass, sarcopenia, and sarcopenic obesity in older adults: A multi-continent study. Journal of Cachexia, Sarcopenia and Muscle, 7: 312-321, 2016. 
2- SUNG K.C., RYU S., LEE J.Y., LEE S., CHEONG E., KIM J.Y., et al.: "All cause, mortality and body mass index in a young Asian occupational cohort without baseline metabolic syndrome components. "International Journal of Cardiology, 224: 271-278, 2016.

3- MELNIK B.C.: Excessive Leucine-mTORC1-Signalling of Cow Milk-Based Infant Formula: The Missing Link to Understand Early Childhood Obesity. International Journal of Obesity, 197653: 2090-716, 2012.

4- PULGARON E.R. and DELAMATER A.M.: Obesity and Type 2 Diabetes in Children: Epidemiology and Treatment. Current Diabetes Reports Journal, 14: 508, 2014.

5- De ONIS M., BLOSSNER M. and BORGHI E.: Global prevalence and trends of overweight and obesity among preschool children. The American Journal of Clinical Nutrition, 92: 1257-64, 2010.

6- Elzanaty and associates: Egypt demographic and health survey 2014. Ministry of Health and Population, 172$176,2015$.

7- BASTIEN M., POIRIER P., LEMIEUX I. and DESPRÉS J.P.: Overview of epidemiology and contribution of obesity to cardiovascular disease. Progress in Cardiovascular Diseases Journal, 56: 369-381, 2014.

8- SHELDON E. and LITWIN M.D.: Early lesions of atherosclerosis in childhood and youth: Natural history and risk factors. Journal of American College of Cardiology, 15: 735-10, 2014.

9- VARMA M.C., KUSMINSKI C.M., AZHARIAN S., GILARDINI L., KUMAR S., INVITTI C., et al.: Metabolic endotoxaemia in childhood obesity. BMC Obesity, 3: 3, 2016.

10-NEVES A.L., MOHAMMEDI K., EMERY N., ROUSSEL R., FUMERON F., MARRE M., et al.: Allelic variations in superoxide dismutase-1 (SOD1) gene and renal and cardiovascular morbidity and mortality in type 2 diabetic subjects. Journal of Molecular Genetics and Metabolism, 106: 359-365, 2012.

11- GOKNAR N., OKTEM F., OZEGEN I.T., TORUN E., KUCUKKOC M., DEMIR A.D., et al.: Determination of early urinary renal injury markers in obese children. Pediatric Nephrology Journal, 30: 139-144, 2015.

12- EL-KARAKSY H.M., EL-KOOFY N.M., ANWAR G.M., EL-MOUGY F.M., EL-HENNAWY A. and FAHMY M.E.: Predictors of Non-alcoholic Fatty Liver Disease in Obese and Overweight Egyptian Children: Single Center Study. Saudi Journal of Gastroenterology, Official Journal of the Saudi Gastroenterology Association, 17: 40-46, 2011.

13- SADEGHABADI Z.A., NOURBAKHSH M., ALAEE M., LARIJANI B. and RAZZAGHY-AZAR M.: Peroxisome proliferator-activated receptor gamma expression in peripheral blood mononuclear cells and angiopoietinlike protein 4 levels in obese children and adolescents. Journal of endocrinological investigation, 41: 241-247, 2018.

14- BOODAI S.A., CHERRY L.M., SATTAR N.A. and REILLY J.J.: Prevalence of cardiometabolic risk factors and metabolic syndrome in obese Kuwaiti adolescents: Diabetes, Metabolic Syndrome and Obesity. Targets and Therapy, 7: 505-511, 2014.
15- EL-KARAKSY H.M., EL-RAZIKY M.S., FOUAD H.M., ANWAR G.M., EL-MOUGY F.M. and EL-KOOFY N.M.: The value of different insulin resistance indices in assessment of non-alcoholic fatty liver disease in overweight/ obese children. Diabetes and Metabolic Syndrome: Clinical Research and Reviews, 9: 114-119, 2015.

16- SANTOMAURO F., LORINI C., PIERALLI F., NICCOLAI G., PICCIOLLI P., VEZZOSI S., et al.: Waist-toheight ratio and its associations with body mass index in a sample of Tuscan children in primary school. Italian Journal of Pediatrics, 43: 53, 2017.

17- HARTE A.L., VARMA M.C., TRIPATHI G., McGEE K.C., AL-DAGHRI N.M., AL-ATTAS O.S., et al.: High Fat Intake Leads to Acute Postprandial Exposure to Circulating Endotoxin in Type 2 Diabetic Subjects. Diabetes Care, 35: 375-382, 2012.

18- SCHWANDER F., KOPF-BOLANZ K.A., BURI C., PORTMANN R., EGGER L., CHOLLET M., et al.: A dose-response strategy reveals differences between normalweight and obese men in their metabolic and inflammatory responses to a high-fat meal. Journal of Nutrition, 144: 1517-23, 2014

19- AEBERLI I., GUT-KNABENHAS I., KUSCHEAMMANN R., MOLINARIC L. and ZIMMERMANN M.B.: Waist circumference and waist to height percentiles in a nationally representative sample of 6-13 years old children in Switzerland. Swiss medical Weekly, 141: 127132, 2011.

20- MUSHTAQ M.U., GULL S., ABDULLAH H.M., SHAHID U., SHAD M.A. and AKRAM J.: Waist circumference, waist-hip ratio and waist-height ratio percentiles and central obesity among Pakistani children aged five to twelve years". BMC Pediarics BMC, 11: 105, 2011.

21- ABD-ELGHAFAR S., HAFEZ M.H., SHAABEN F.A., ABO ESMAIL L.A., SALAMA S.L. and RASHED R.G.: Resistin and obesity associated insulin resistance in children. Journal of Genetic Engineering and Biotechnology, 8: 17-25, 2010.

22- SAKI F. and KARAMIZADEH Z.: Metabolic syndrome, insulin resistance and Fatty liver in obese Iranian children. Iranian Red Crescent Medical Journal, 16: 5, 2014.

23- HASSAN N.E., ATEF A., EL-MASRY S.A., IBRAHIM A., AL-TOHAMY M., RASHEED E.A., et al.: Is Neck Circumference an Indicator for Metabolic Complication of Childhood Obesity?. Open access Macedonian Journal of Medical Sciences, 3: 26, 2015.

24- MAFFETONE P. and KHOPKAR M.: The overfat pandemic in India. Global Epidemic Obesity, 6: 2, 2018.

25- Nawarycz T., Haas G.M., KRZYZANIAK A., SCHWANDT P. and OSTROWSKA-NAWARYCZ L.: Waist circumference and waist-to-height ratio distributions in Polish and German school children: comparative analysis. International Journal of Preventive Medicine, 4: 786, 2013.

26- DONMA M.M. and DONMA O.: The importance of some new clinical indices in the Evaluation of Childhood Obesity. LIFE: International Journal of Health and LifeSciences, $3:$ 16-28, 2017.

27- JEHN M.L., GITTELSOHN J., TREUTH M.S. and CABALLERO B.: Prevalence of Overweight among Baltimore City School children and its Associations with 
Nutrition and Physical Activity. The official journal of The Obesity Society, 14: 989-993, 2006.

28- RINALDI A.M., PIMENTEL G.D., PEREIRA A.F., GABRIEL G.F., MORETO F. and BURINI R.C.: Metabolic syndrome in overweight children from the city of Botucatu - São Paulo State - Brazil: Agreement among six diagnostic criteria. Diabetology and Metabolic Syndrome Journal, 2: 39, 2010.

29- KOLLIAS A., SKLIROS E., STERGIOU G.S., LEOTSAKOS N., SARIDI M. and GARIFALLOS D.: Obesity and associated cardiovascular risk factors among school children in Greece: A cross-sectional study and review of the literature. Journal of Pediatric Endocrinology and Metabolism, 24: 929-938, 2011.

30- WANZHU T.U., ECKERT GJ., DiMEGLIO L.A., ZHANGSHENG Y.U., JUNG J. and PRATT J.H.: Intensified Effect of Adiposity on Blood Pressure in Overweight and Obese Children. Hypertension, 58: 818-824, 2011.

31- LIN J.F., HSU S.Y., WU S., TENG M.S., CHOU H.H., CHENG S.T., et al.: QT interval independently predicts mortality and heart failure in patients with ST-elevation myocardial infarction. International Journal of Medical Sciences, 12: 968, 2015.

32- GIANNINI D.T., KUSCHNIR M.C.C. and SZKLO M.: Metabolic syndrome in overweight and obese adolescents: A comparison of two different diagnostic criteria. Annals of Nutrition and Metabolism, 64: 71-79, 2014.
33- LEE L. and RAUSCH M.E.: Metabolic syndrome. Pediat. Rev., 33: 459-466, 2012.

34- ZOAIR A.M., MUHAMMAD K.T., ABU-AMMO D.E. and MOTAWEA M.M.: Lipid profile and some cardiac function in children with obesity. Egyptian Pediatric Association Gazette, 61: 15-22, 2013.

35- KLOP B., ELTE J.W.F. and CASTRO CABEZAS M. Dyslipidemia in Obesity: Mechanisms and Potential Targets. Nutrients, 5: 1218-1240, 2013.

36- LIANG H., HUSSEY S.E., SANCHEZ-AVILA A., TANTIWONG P. and MUSI N.: Effect of Lipopolysaccharide on Inflammation and Insulin Action in Human Muscle. PLoS one Journal, 8: 5, 2013.

37- COX A.J., WEST N.P. and CRIPPS A.W.: Obesity, inflammation, and the gut microbiota. The lancet Diabetes and endocrinology Journal, 3: 207-215, 2015.

38- DEOPURKAR R., GHANIM H., FRIEDMAN J., ABUAYSHEH S., SIA C.L., MOHANTY P., et al.: "Differential effects of cream, glucose, and orange juice on inflammation, endotoxin, and the expression of Toll-like receptor-4 and suppressor of cytokine signaling-3. Diabetes Care, 33: 991-7, 2010.

39- MANI V., HOLLIS J.H. and GABLER N.K.: Dietary oil composition differentially modulates intestinal endotoxin transport and postprandial endotoxemia. Nutrition and Metabolism , $10: 6,2013$.

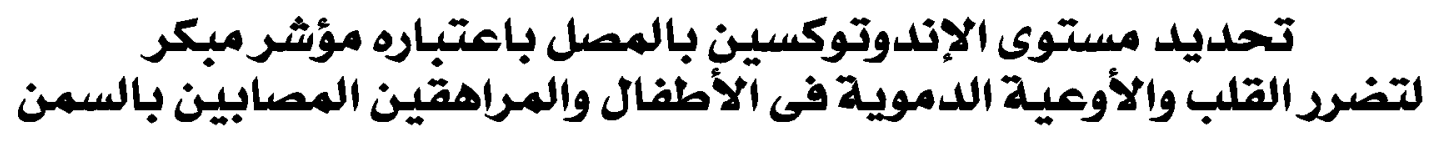

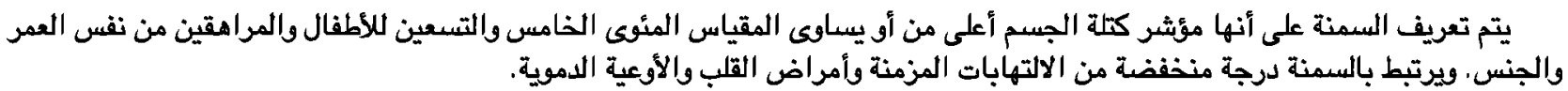

الهدف من البحد: هو تصديد مستوى الاندوتوكسين بالمصل فى الأطفال والمراهقين المصابين بالسمنة وتقييم علاقته بمخاطر أصابة

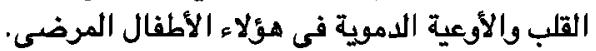

وطرق البحث: أجريث الدراسة الحالية على • ب طفل من المصابين بالسمنة بوحدة التغذية، قسم طب الأطفال، مستشفى جامعة طنطا

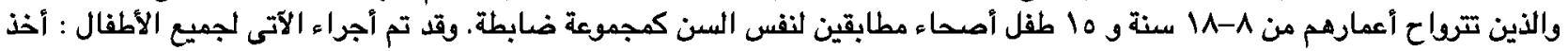

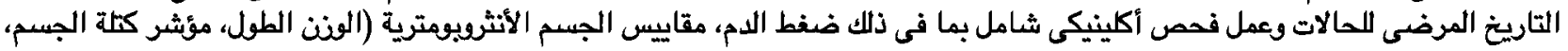

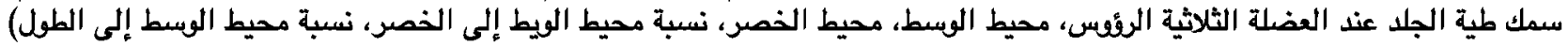

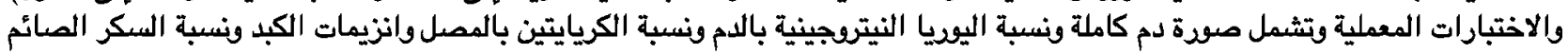

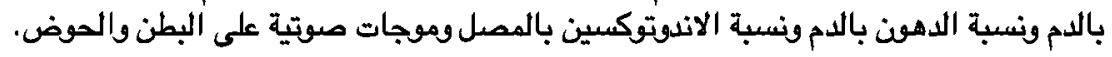

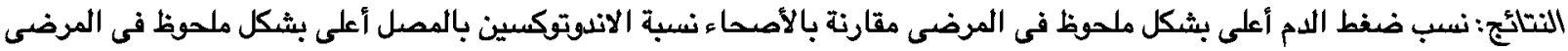

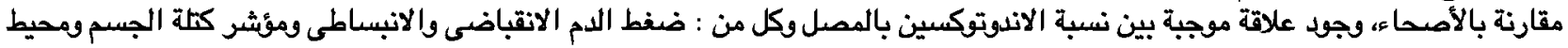

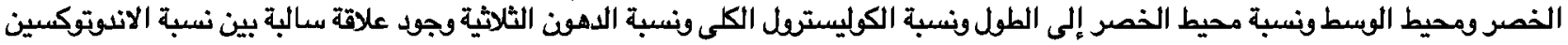
بالمصل والبرتين الدهنى عالى الكثافة.

الاستتاج: نسبة الاندوتوكسين بالمصل أعلى بشكل ملحوظ في الأطفال والمراهقين المصابين بالسمنة مقارنة بالأصحاء وأن قياس مستوى نسبة الاندوتوكسين بالمصل يعتبر مؤشر مبكر لتضرر القلب والأوعية الدموية في الأطفال والمراهقين المصابين المقالين بالسمنة.

التوصيات: ضرودة متابعة قياس ضغط الدم للاطفال ، مؤثرات السمنة المركزية ونسبة الدهون بالدم في الأطفال بالسمنة لأنهم مؤثرات

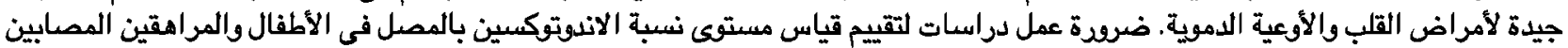

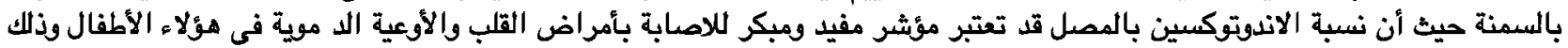

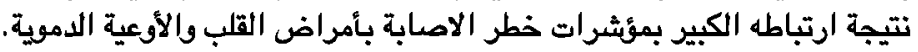

